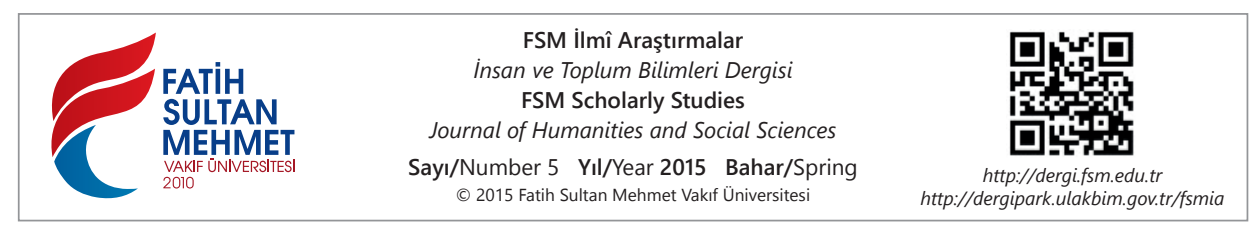

\title{
Klasik Türk Şiirinde Estetik Bir Unsur Olarak Çiçekler
}

Berat Açı|*

\section{Özet}

İslamî edebiyatların bir kolu olan klasik Türk şiirinin estetik yargıları da Grek estetiğinden çokça etkilenmiş olan İslam estetiğinin etkisi altında şekillenmiştir. Klasik Türk şairleri bütünlük, harmoni, simetri ve orantı gibi estetiğin temel özelliklerinin yanı sıra işleve de büyük önem verirler. Kullandıkları her bir estetik nesnenin aynı zamanda bir işlev yüklenmesini bekleyen klasik Türk şairleri, icazlı söz söyleme hedefine ulaşmak için eserlerinde çiçeklere de yer vermişlerdir fakat klasik Türk şiirinde kendine yer bulan çiçek sayısı azdır. Bunun temel nedeni, klasik Türk şiiri estetiğine dâhil edilmekle birlikte söz konusu estetiğe işlevsel katkılarda bulunabilen çiçeklerin sayıca sınırlı olmasıdır. Bir diğer ifadeyle, bu şiirde kendine yer bulan sadece on dokuz çiçek klasik Türk şiiri estetiği içinde birer işlev yüklenebilmiş ve şiire konu olabilmişlerdir.

Anahtar kelimeler: Klasik Türk şiiri, estetik, çiçekler, İslam estetiği.

\section{Flowers as an Aesthetical Element in the Classical Turkish Poetry}

\section{Abstract}

The aesthetic statutes of Classical Turkish literature which is a branch of Islamic literatures, are under the control of Islamic aesthetics that is highly influenced by the Greek aesthetics. Classical Turkish poets in addition to integrity, harmony, symmetry and proportion, which are the main characteristics of the aesthetics, pay special attention to function. The classical Turkish poets who demand from every single aesthetic object to have a function, use flowers in their works to reach their goals of succinctness (icaz) but there are relatively few kinds of flowers used in the classical Turkish poetry. The main reason of the fact is that there are few flowers in number which is included into classical poetry that can be used as a manner of function for the aesthetics of classical Turkish poetry. To put another way, only nineteen flowers used in this poetry have some aesthetical functions and are subject to poetry in general.

Keywords: Classical Turkish poetry, aesthetics, flowers, Islamic aesthetics.

* Yrd. Doç. Dr., İstanbul Şehir Üniversitesi İnsan ve Toplum Bilimleri Fakültesi Türk Dili ve Edebiyatı Bölümü, İstanbul/Türkiye, beratacil@sehir.edu.tr 


\section{Giriş*}

İslamî edebiyatların bir kolu olan klasik Türk edebiyatının temel estetik unsurları, Arap ve Fars edebiyatlarının estetik değerleri gibi İslam düşüncesinden beslenmiştir. Güzel ve güzellik kavramlarıyla ilintili olan estetik, haddizatında güzel olan çiçeklerle de sıkı bir ilişki içindedir. Türk tarihi, mitolojisi ve geleneklerinin yanı sıra Arap ve Fars edebî geleneklerinin de etkisiyle gelişimini tamamlamaya çalışan klasik Türk şiirinin estetik birer nesne olarak bünyesine aldığ 1 çiçekler, bu edebiyatta ilk defa ne zaman kullanılmıştır? Çiçeklerin klasik Türk şairleri tarafından estetik birer obje olarak sıkça kullanılmalarının nedenleri nelerdir? Hangi çiçekler klasik Türk şiirinde kendilerine yer bulabilmişlerdir? Bununla bağlantılı olarak söz konusu çiçeklerin kullanılma amaçları ve biçimleri hakkında neler söylenebilir? Tüm bu soruların ve yanıtlarının klasik Türk şiiri estetiği içinde/açısından, klasik Türk şiirini daha iyi kavramak bakımından bir anlamı var mıdır? Bu makalede, yukarıdaki ve benzeri soruların yanıtları hem estetik gibi nispeten soyut bir düzlemde hem de şiirlerin bizzat kendileri gibi tatbikî/somut bir düzlemde aranacaktır. Bunun için nazari olarak estetik ve İslâm estetiğinden söz edildikten sonra, somut düzlemde çiçeklerin ilk defa estetik zevk için yetiştirildiği bahçelerden ve bu bahçelerin söz konusu estetikle ilişkisinden bahsedilecek, son kısımda ise klasik Türk şiirinde çiçeklerin kullanımına odaklanılarak estetik içinde çiçeklerin yeri tespit edilmeye çalışılacaktır. Elinizdeki makalenin temel tespiti ve buna dayanan iddiası şudur: Klasik Türk şiirinde az sayıda çiçek kullanılmıştır ve bu azlığın nedeni estetiğin bizzat kendisidir çünkü klasik Türk şiiri estetiği az sayıda farklı çiçek türünün kullanılmasını zaruri kı1mıştır. Klasik Türk şiiri estetiğine uygun olmayan veya söz konusu estetik içine dâhil edilemeyen çiçekler ya hiç kullanılmamıştır ya da önemsiz denecek kadar seyrek kullanılmıştır.

\section{Grek Estetiği}

En genel hâliyle "güzel"e dair söz söyleme bilimi olarak tanımlanabilecek estetik, genelde sanatın özelde edebiyatın anlaşılmasında mutlaka irdelenmesi gereken bir konudur. Sanat ve edebiyat tarihin ilk dönemlerinden bu yana var olageldiklerine göre estetiğe dair kimi düşüncelerin de ilk zamanlardan beri serdedildikleri varsayılabilir. Fakat, elimize ulaşan yazılı kaynaklara göre estetikle ilgili ilk sistematik düşünceler, kadim Yunan gibi insanlık tarihinin nispeten geç bir dönemine tarihlenmektedir. Yunan filozoflarının en etkililerinden biri olan Platon, estetik hakkında ilk sistematik teoriyi ortaya koymuş kişi gibi görünmektedir. Platon, doğrudan estetikle ilgili bir kitap kaleme almamış olmakla beraber Büyük Hippias adlı eserinde estetikle ilgili ilk temellendirmelerini yapmıştır. Ona

* Bu makalenin değişik biçimlerini okuma nezaketinde bulunan Hatice Aynur, Didem Havlioğlu ve Betül Sinan Nizam'a minnettarım. 
göre duyular dünyası ve akıl (idealar) dünyası birbirinden ayrı iki dünyadır. ${ }^{1}$ Platon birbirinden ayrı iki dünya olduğu yargısına vardıktan sonra yaşadığımız dünyanın idealar dünyasının bir temsili mesabesinde olduğu sonucuna varır. "Ona göre 'İdea', bütün genel geçerlik taşıyan yasaların, kuralların, varlık türlerini oluşturan ilkelerin değişmez, ölümsüz ve hakiki karşılı̆̆ıdır. Varlık türlerinin ve bireylerin sayısınca 'İdea' vardır." ${ }^{2} \mathrm{Bu}$ düşünce de Platon'un meşhur "mağara alegorisi” fikrini ortaya çıkarmıştır. Mağara alegorisine göre varlık olarak algıladığımız her şey aslı idealar dünyasında olan birer kopyadan ibarettir. Sanat eseri de ideaların bir yansıması (kopyası) olan bu dünyadaki gerçekliği yansıttığı/ taklit ettiği için asıldan/ideadan iki kez uzaklaşmış olmaktadır. Bundan dolayı da yanıltıcıdır. Sanatın bu özelliğine rağmen insanları kandırmaya çalışmayan "iyi” sanat eserleri de yok değildir. Platon'a göre iyi bir sanat eseri şu özellikleri barındırmalıdır: "kendinde bütünlük", "simetri, armoni ve orantı". "İyi yapılmış bir sanat eseri, form yetkinliğine ve kullanılan yöntemin güvenilirliğine sahiptir; bunlardan ikincisi sanat yapıtının kendinde bir bütünlügünün olmasını ve yapıtın kendi içinde bir etkinliğinin bulunmasını să̆lar. Böylece güzel sanat eserinin oluşmasını sağlayan temel ögeler arasında simetri, armoni ve orantının bulunduğunu görürüz."’3

Platon'un öğrencisi Aristoteles, hocasına ilk ciddi eleştirileri yönelten kişi olmuştur. Aristoteles de yukarıda zikredilen özellikleri kabul etmekle beraber Platon'un “idealar" düşüncesine karşı çıkar. O, hocasının hilafına, bu dünyanın gerçek olduğu görüşündedir. Ona göre idealar insan zihninin soyutlamalarından ibarettir. ${ }^{4}$ Meseleye böyle yaklaşıldığında sanatın gerçeklikten uzaklığı sorunu da ortadan kalkmış olur. "Aristoteles'de sanat, taklit (mimesis) ile başlar, arınma (katharsis) ile son bulur." ${ }^{5}$ Ona göre sanat, arınma yoluyla kişinin doğruyu bulmasına yardımcı olmaktadır. Bu bağlamda, Aristoteles'in sanata Platon'dan daha olumlu bir gözle baktığını söyleyebiliriz. İslâm sanatına geçmeden evvel, İslâm düşüncesini daha çok etkilediği iddia edilen bir ara halkadan daha kısaca söz edilmelidir: Yeni Platonculuğun kurucusu Plotinos. İslâm felsefesi ile Grek felsefesi arasında bir geçiş noktası olarak görülen Plotinos, Platon'u yeniden yorumlamıştır.

“Platon'un gidimli (discursif) bilgisine karşılık Plotinos'da karşımıza çıkan görme bilgisi, bir tür özel görmeye (vision) dayanan bilgidir. Gizli şeyleri gönül gözüyle görme, bir tür mistik görüş olan bu görüş biçiminde bilen ile bilinen aynı şeydir. Ona göre İyi'nin güzelliği, estetiğin hakiki karakterini verir. Öte yandan

\footnotetext{
1 Suut Kemal Yetkin, Estetik Doktrinler, İstanbul, Palme Yayıncılık, 2007, s. 4-5.

2 Nejat Bozkurt, Sanat ve Estetik Kuramları, İstanbul, Sarmal Yayınları, 1995, s. 81.

3 Bozkurt, a.g.e., s. 98.

4 Yetkin, a.g.e., s. 8.

5 Bozkurt, a.g.e., s. 99.
} 
İyi, Bir, Form ve her şeyin kaynağı olan Tanrı özdeştir, bir ve aynı şeydir.”6

Burada bir nevi varlık birliğinden söz edilebilir. Bilen, bilinen, nesne, obje ayrımları Platon ve Aristoteles'e göre biraz daha silikleştirilmiştir. Bu bakış açıs1, İslam estetik anlayışıyla benzerlikler gösteren bir estetik düşüncenin izlerini taşımaktadır.

\section{İslam Estetiği}

Klasik Türk şiiri için yaygın bir kanaatten sıkça söz edilir: Klasik Türk şairleri malumu ilam etmezler. Bunun nedeni, okurların büyük çoğunluğunun aynı zamanda şair veya yazar olmalarıdır. Dolayısıyla edebiyat geleneğini oluşturan motifler, mazmunlar, remizler vb. hem bu edebiyatın şair/yazarları hem de okurları tarafından çok iyi bilinmektedir. Bundan dolayı söz konusu bilginin anlatılmasına da ihtiyaç duyulmamıştır. Klasik Türk şiirine has gibi algılanan bu durum İslam estetiği konusunda da tezahür etmektedir. İrvin Cemil Schick, İslam geleneğinde estetik hakkında neredeyse hiç yazılmamış olduğunu belirttikten sonra, her şeye rağmen kimi düşünürlerin estetik olgular hakkında fikir beyan etmiş olduklarını belirtir. Buna örnek olarak da optik alanındaki çalışmalarıyla bilinen İbnü'l-Heysem'den (ö. 1040) söz etmekte ve onun güzellikle ilgili olarak "her şeyin farklı derecelerde sahip olduğu bir amaçtır ve düzen, oran ve harmoni gibi niteliklerce ölçülebilir. "’ dediğini aktarır. Bu alıntıda "düzen, oran ve harmoni” kelimeleri tanıdıktır. Platon'dan başlayarak Grek estetik düşüncesinden intikal eden bir düşüncenin on birinci yüzyılda bir İslam düşünürünün kalemine aksetmiş izleridir bunlar. Fakat yine de arada önemli bir fark yok değildir: İleride Türk bahçeciliğiyle ilgili aktaracağımız bir iddiaya benzer şekilde burada "amaç" kelimesinin kullanılmış olmasını özellikle vurgulamak gerekir. Bu da, İslam estetiğini tahlil ederken "amaç"1 veya "işlev"i de göz önüne almak zaruretini ortaya koymaktadır. Şu aşamada iddialı görünecek bir biçimde, "amaç" veya "işlev"in İslam estetiğinin ayırıcı özelliği olduğunu söylemek de imkân dâhilindedir.

Grek estetik ve sanat felsefesinde geçerliliğini sürdürmekte olan tartışmalardan bir diğeri de mimesis (taklit, yansıtma) kavramıdır. Bu düşünceye göre, sanat reel dünyayı kopya eder. Dolayısıyla sanata bir taklit veya yansıtma gözüyle bakılabilir. Bu düşüncenin yakın zamandaki temsilcilerinden biri, ünlü romanc1 Stendhal'dır. Ona göre "Roman, uzun bir yol üzerinde dolaştırılan bir aynadır". 8

6 Bozkurt, s. 115. Gidimli bilgi, aslında Platon'a göre dört bilgi türünden yalnızca biridir. Ona göre bilgi; sanı, iman, istidlal ve idrak olmak üzere derecelenmektedir. Gidimli bilgi, denen bilgi aslında istidlali bilgidir. Platon, Devlet, Çev. Sabahattin Eyüboğlu-M. Ali Cimcoz, İstanbul, İş Bankası Yayınları, 2009, s. 226-228.

7 İrvin Cemil Schick, "Aesthetics and Islamic Calligraphy”, Eternal Letters, adl1 sergide sunulmuş tebliğ, Sharjah, s. 1.

8 Henri Beyle Stendhal, Kırmızı ve Siyah, Çev. Cevdet Perin, İstanbul, Remzi Yayınevi, 2002, s. 435. 
İslam estetiği ise, sanatın hakikati gerçekliğe/reel dünyaya ayna tutarak yansıtacağını düşünmez. Ona göre kâinat bir remizler âlemidir. Sanatçıya düşen, remizlerin hakikatini öğrenmeye, anlamaya çalışmaktır. Böyle olunca Platon'un düşüncesinin aksine ikisi de gerçek ama biri diğerinin remzi olan iki dünya arasında duran sanatçı bu dünyanın işaretlerinden yola çıkarak öte dünyanın hakikatini anlama çabasına girişir. Walter Andrews şöyle yazar: "Bu dünyanın nesneleri, ancak öteki dünyadaki misalleri sayesinde anlam kazanırlar". ${ }^{9}$ Hâliyle bu dünyadaki tüm nesnelerin birer anlamı, birer göndergesi veya işaret ettikleri birer hakikat vardır. Dolayısıyla her bir nesneye ihtimam göstermek, onlara hakikatin bir işaretçisi gözüyle bakmak gerekir. Maddi dünyaya ait tüm nesneler gibi bahçe ve çiçekler de klasik Türk şiirinde bu gözle görülmüş ve yorumlanmıştır. Klasik Türk şiirinde çiçek algısına geçmeden önce çiçeklerin estetik zevk için yetiştirildiği mekânlar olması hasebiyle Türklerde bahçe ve bahçe kültürünün gelişimine kısaca göz atmak yerinde olacaktır.

\section{Estetik Birer Nesne Olarak Türk Bahçeleri}

Türk edebiyatında doğada görülen ve edebiyata aksettirilen çiçeklerin estetik birer kullanıma kavuşması Türklerin göçebe yaşam tarzından yerleşik yaşam tarzına geçmeleriyle mümkün olmuştur. Bu geçişin maddî göstergesi de yerleşik hayatla beraber görülmeye başlanan ve sosyal yaşamın ayrılmaz bir parçası hâline gelen bahçe kültürüdür.

Türklerin yerleşik hayata nispeten geç bir tarihte geçtikleri genelde kabul gören bir görüştür. Dolayısıyla Türklerde bahçe kültürünün de geç tarihlerde geliştiğine dair bir kanaat hâs1l olmuştur. "Göçebe gelenekleri olan ve geçimini kurak yerlerden sağlamış bir milletin toprağı hem sürekli, hem de salt zevk için düzenleme kavramın ancak devletin yerleştiğine ve koruyucu kudretine mutlak inancının yer edişinden sonra benimsemiş olması pek tabiidir." ${ }^{10}$ Gönül Aslanoğlu Evyapan, bahçe kültürünün ortaya çıkışını; yerleşik hayat, devlet ve istikrar gibi kavramlara bağlamaktadır. Bu gibi kavramlar aynı zamanda sanatın da kök salmak için ihtiyaç duyduğu zaruretlerdir. Böyle bir bakış açısıyla Türklerde bahçe kültürünün yukarıda sayılan üç faktörün bir arada sağlandığı dönemlerden sonra veya onlarla eş zamanlı geliştiği düşünülebilir.

Osmanlı döneminde kimliğini kazanmış Türk bahçelerinin Selçuklu bahçelerinden etkilenmiş olduğu varsayılmaktadır. Osmanlı dönemi Türk bahçeleri de kendi içinde sanatın geneline uygun bir şekilde gelişim göstermiştir. Hilal Turgut, gelişimi içinde Osmanlı bahçelerinin hususiyetlerini şöyle aktarır:

9 Walter G. Andrews, Şiirin Sesi Toplumun Şarkısı, Çev. Tansel Güney, İstanbul, İletişim Yayınlar1, 2003, s. 90.

10 Gönül Aslanoğlu Evyapan, Eski Türk Bahçeleri ve Özellikle Eski İstanbul Bahçeleri, Ankara, Ortadoğu Teknik Üniversitesi, 1972, s. 9. 
“Osmanlı Devleti'nin kuruluşundan İstanbul'un fethine kadar olan dönemde bahçelerde Selçuklu sanatının izleri görülmektedir. Bu dönemde avlu bahçeleri ön plandadır. Avlularda simetri yoktur. Gölge için çınar, çitlembik, servi ağaçlarına yer verilir. Zemin taş ile kaplanmıştır. İstanbul'un fethinden Lale Devri'ne kadar olan dönem içerisinde Osmanlı bahçe anlayışını Topkapı ve Üsküdar Saraylarında görmek mümkün olmuştur. Lale devrinin (1703-1730) başlamasıyla birlikte, sadeliğiyle ön plana çıkan bahçeler, yerini planlı bahçelere bırakmıştır."

Burada vurgu, sadelik ve kullanışlılık ile planlılık ve görsellik arasındaki fark üzerinde yoğunlaşmaktadır. “Topkapı Sarayı'na kadar bahçeler ve beraberindeki havuzlar yaşanabilir mekanlar olarak tasarlanmıştır. Daha sonraki yıllarda görsel etkinin öne çıktı̆̆l görülmektedir." ${ }^{2}$ Netice itibariyle, Türk bahçelerinde yaşanabilir olandan seyredilebilir ve içinde gezilebilir olana doğru bir dönüşüm çizgisi izlendiği görülmektedir.

Zamanla kendi içinde estetik dönüşümler geçiren Türk bahçeleri Osmanlı dönemi ve günümüzde Batı toplumlarıyla etkileşimin bir neticesi olarak Batı'daki bahçelerle de kıyaslanmıştır. Türk bahçelerinin estetik hususiyetlerinin ayrıntılı incelenmesi başka bir çalışmanın konusu olabilecek genişlikte olduğundan söz konusu bahçelerin İslam estetiğine bağlanan ve Batı bahçelerinden ayrılan bir yönüne temas etmekle iktifa edeceğiz. Türk bahçeleri ve Batı bahçeleri arasında önemli bir farka dikkat çeken Evyapan şunları yazar: "Türk bahçelerini batı bahçelerinden ayıran en önemli yön kullanışlılı̆̆a verilen bu ă̆ırlık olmuştur." 13 Türk bahçelerinin bu özelliği yukarıda İslam estetiği için dile getirdiğimiz olas1 ayırıcı özellik fikrini destekler mahiyettedir. İbnü'l-Heysem'den aktardığımız cümlelerde Grek estetik düşüncesinden devralınmış kimi ibarelerin yanı sıra "amaç", "işlev" gibi kelimeler de "güzellik" tanımında yer almaktaydı. Buradan hareketle İslam estetiğinde "işlev"in de önemli bir yer tuttuğunu belirtmiştik. Evyapan'ın “kullanışlılık”la ilgili bu iddiası İslam'ı din olarak seçmiş Türklerin de estetik düşüncelerinde aynı vurguya sahip çıktıklarını göstermektedir. Zamansal açıdan Osmanlı devletinin hüküm sürdüğü dönemlerde hayatiyet bulan klasik Türk edebiyatının yerleşik hayata geçmiş, tarımla uğraşan ve estetik zevk için bahçeler tesis etmeye başlamış bir toplumda görünür hâle gelen çiçeklerden estetik birer obje olarak faydalanması doğaldır.

Türk edebiyatında çiçeklerden ilk söz eden eser olarak Divânü Lügati t'-Türk anılabilir. Söz konusu eserde çiçekler, ne klâsik Türk edebiyatının birer estetik unsur olarak beliren çiçekleri ne de "kültür" (insanlar tarafından yetiştirilmiş) çiçekleridir.

11 Hilal Turgut, “Tarihi Türk Bahçelerinde Havuz Yapıları”, Tarih Kültür ve Sanat Araştırmaları Dergisi, say1 1/3, 2012, s. 121.

12 Turgut, a.g.m., s. 132.

13 Evyapan, a.g.e., s. 55. 
"Sözü edilen çiçeklerin hepsi, hiç şüphesiz, kır çiçekleridir. Göçebenin bahçeler tanzim edip kültür çiçekleri yetiştirmeye vakti yoktu. Yerleşik hayata çok erken geçenler de bulunmakla beraber, atalarımız genel olarak göçebe idi, bu bir gerçek. Göçebeliğin ilkellik olduğunu zannedenler itiraz ediyorlar, ama biz öyle düşünmüyoruz. Göçebelik ilkellik değil, kendine göre üstünlükleri olan farklı bir yaşama biçimi." 14

Beşir Ayvazoğlu, Dede Korkud Kitabı'nda da çiçeklerin “iyileştirici” özellikleriyle şiire konu edildiklerini, çiçeklerin “işlev”lerine yoğunlaşıldığını söylemektedir. ${ }^{15}$

Osmanlı imparatorluğunun güçlenmeye başladığı ve toplumun büyük kesiminin yerleşik bir hayat tarzına geçtiği bir dönemde insanların devlete istikrar açısından güven besledikleri düşünülebilir. Böyle bir dönemde ilk önemli eserlerini vermeye başlamış olan klasik Türk edebiyatının (genellikle 15. yüzyılda klasik Türk şiirinin müesses hâle gelmeye başladığı düşünülür) bahçe kültürünün tezahür etmiş olduğu bir ortama doğduğu varsayılabilir.

“Klasik Türk şiirinin hüküm sürdüğü dönem, Türklerin yerleşik hayata iyice alıştıkları ve artık geçimlerini hayvancılık yanında büyük oranda tarımdan sağladıkları bir dönemi kapsamaktadır. Ayrıca yerleşik hayatla birlikte çevrenin güzelleştirilmesi çabasıyla bağlantılı olarak estetik amaçlı alışkanlık ve gelenekler de iyice yerleşmeye başlamıştır." 16

Çok iyi birer gözlemci olan klasik Türk şairlerinin doğada gördükleri veya bahçelerinde yetiştirdikleri çiçekleri estetik birer unsur olarak şiirlerinde kullanmaya nispeten erken dönemlerde başladıklarını söyleyebiliriz. Bu konunun ayrıntısına geçmeden önce çiçeklerin estetik kullanımı ibaresinden neyi kastettiğimizi daha açık ifade etmemiz gerekmektedir.

\section{Çiçekler ve Estetik}

Hem klasik Türk şiirinde hem de genel olarak İslam sanatında çiçekler ve çiçeklerin estetik kullanımından kastedilen daha çok soyutlama kavramıdır. Bu kavram yerine Ayvazoğlu, üsluplaştırma kavramını kullanmayı tercih etmektedir. Bir çiçeğin gerçek, görünür, maddi tezahüründen ziyade, tüm bunların etkisiyle oluşmakla beraber zihinlerde uyanan imajıyla kullanılmasıdır üsluplaştırma. Ayvazoğlu, "Esasen tezhip stilize edilmiş çiçeklerin sanatıdır."17 derken, üsluplaştırmayı

14 Beşir Ayvazoğlu, Güller Kitabı, İstanbul, Ötüken Yayınları, 1997, s. 23.

15 Ayvazoğlu, Güller Kitabı, s. 25.

16 Yavuz Bayram, "Klasik Türk Şiirinde Duyguların Dili: Çiçekler”, Turkish Studies International Periodical For the Languages, Literature and History of Turkish or Turkic, say1 2/4, 2007, s. 209-10.

17 Ayvazoğlu, Güller Kitabı, s.17. 
kastetmektedir. Ona göre "Üsluplaştırmanın metafizik anlamı, objeleri paranteze alarak yok saymak, başka bir deyişle, eşyayı objektif niteliklerinden soyarak öze ulaşmaya çalışmaktır" ${ }^{18}$ Böyle bir bakış açısıyla sanatçının bir çiçek resmetmek için karşısında bir çiçek olmasına gerek yoktur; zihninde zaten bir çiçek imajı oluşmuştur. Bu stilizasyon, üsluplaştırma veya soyutlama vasıtasıyla çiçeğin maddi boyutu "paranteze alınmış", onun İslamî estetik içinde yüklendiği manevî anlamı öne çıkarılmış ve sanatçı tarafından görünür kılınmaya çalışılmıştır. Bu da, Ayvazoğlu'nun deyişiyle "öz"dür. İslam sanatçılarının mesela nakkaşların zihinlerine nakşettikleri imajlardan çekip çıkardıkları malzemeyle sanatsal üretimde bulundukları bilinen bir gerçektir. Bir objeden (burada çiçek) zihindeki imajı vasıtasıyla yararlanmak onun gerçeklikle ilgisinin kopukluğu anlamına gelmemelidir. Estetik yargıların ve geleneğin oluşturduğu bakış açısından o obje görüle görüle kanıksanmış bulunmaktadır. Çok iyi birer gözlemci olan şairlerin de göre göre kanıksadıkları objeleri estetik yargılar ve geleneksel kullanımlar çerçevesinde soyutlamaları gözlemciliğin bir üst basamağı olarak algılanabilir. Nitekim Turan Koç bu konuda şunları yazmaktadır:

"Bu sanatın ayırt edici özelliklerinden biri de soyutlamaya son derece büyük bir yer ve önem vermesidir. Bütün İslâm sanatları görünende görünmeyeni, değişende değişmeyeni yakalama ve gösterme cehd ve çabasında olduğundan, tabiatı olduğu gibi aksettirmek yerine onu soyutlamaya, ele aldığı nesnenin bireyselliğini ve tabiiliğini öldürmeye yönelmiştir... Bununla birlikte geleneksel sanatımız, ne kadar dolaylı ve imalı konuşsa, ne kadar soyutlama ve stilizasyona gitse de reel olandan bütünüyle kopmamıştır." ${ }^{19}$

Nitekim Osmanlı dönemi şairleri de "görünen", "değișen” birer nesne olan çiçeklerde görünmeyen, değişmeyen özü bulma gayretinin bir ürünü olarak güzelliğin, güzelin özünü aramışlardır.

\section{Klasik Türk Şiirinde Estetik ve Çiçekler}

Klasik Türk şiirinde çiçekler, gerçekçi gözleme dayanarak icaz, üsluplaştırma, remiz ve ayetlerin okunması ve anlaşılması ekseninde kullanılmaktadır. Mine Mengi'nin iddia ettiği gibi klasik Türk şiirinin nihai amacı icazlı söz söylemektir. "Öyleyse i'câz; şiirde bir estetik ölçüt; daha doğrusu şairin estetik beklentisi, amacı, şiirde ulaşmayı istediği son nokta, en üst basamak olmalıdır." Bunun nedeni, İslamî bir dünya görüşüne sahip şaire göre sözün en yücesinin Kur'an-1 Kerim'de Allah tarafından i'cazlı bir şekilde söylenmiş olmasıdır. ${ }^{21}$

18 Ayvazoğlu, Güller Kitabı, s. 83.

19 Turan Koç, İslam Estetiği, İstanbul, İSAM Yayınları, 2009, s. 25.

20 Mine Mengi, "Divan Şiiri Estetiği Açısından İcâz”, A. Ü. Türkiyat Araştırmaları Dergisi, sayı 39, 2009, s. 136.

21 Berat Açıl, “Tûtî-i Mu“cize-gûyem: Osmanlı Şiirinin Estetiğì”, Modern Dönemde İslam’ı ve Osmanlı'yı Yeniden Düşünmek, (Ed) Berat Açıl ve M. Hüseyin Mercan, İstanbul, Yedirenk Yay, 2013, s. 29-48. 
Şairin yapabileceğinin en iyisi, Kur'an'daki mucizevî sözü taklit etmektir. İslam inanışına göre tüm kâinat Allah tarafından birer "ayet", işaret olmak üzere yaratılmıştır. Bundan dolayı sanatçı da yeryüzündeki bu işaretleri okumaya, anlamaya çalışmalıdır. Schick, "Kısacası, müminlere düşen görev, Hilkat'i okumak, O'nun her taraftaki işaretlerini idrak etmek ve bunları O'nun kudret ve rahmetinin kanıtı olarak doğru yorumlamaktır." 22 derken kâinatı bir metin olarak yorumlamaktadır. Ona göre İslam sanatlarının önemlilerinden biri olan "hat sanatı da salt metni en güzel biçimiyle muhafaza etmenin değil, ayn zamanda insan eserlerinde Yaradan' 'n alâmetini kayda geçirmenin de bir yoludur"23 İslam estetiğinin Grek estetiğinden ayrılan noktalarından bir tanesi de bu düşüncede yatmaktadır: Mimesis yerine okuma / anlama ameliyesi ikame edilmiştir.

Şair okuduğunu, anladığını gündelik sözlerle ifade etmek yerine sanatsal bir dille ifadeye yönelir yani tasannu peşindedir. Bundan mütevellit üsluplaştırma, stilizasyon gibi taktikleri kullanır. Fakat tüm bu soyutlamaların, taktiklerin çıkış noktası gerçekçi gözlemdir. Aşağıdaki örneklerde de görüleceği gibi klasik Türk şairleri, nesneyi en ince ayrıntısına kadar gözlemledikten sonra onu şiirlerine konu edinirler. Aynı kaide çiçekler için de geçerlidir.

Burada önemli bir soru akla gelmektedir: Neden klasik Türk şiirinde kullanılan çiçek sayısı sınırlıdır? Eğer bu şiir gözleme dayanıyorsa, şairler tüm çiçekleri gözlemlemiyorlar mıydı? Bu soruların yanıtını biribiriyle bağlantılı iki unsurda aramak gerekmektedir: Bahçe kültürü ve İslam estetiğine dâhil edebileceğimiz klasik Türk şiiri estetiği. Bir diğer ifadeyle, bahçe kültürü içinde yetiştirilmiş ve daha çok şehirlerde görülen; dolayısıyla yukarıda değinilen estetik algıya uygun olan çiçekler klasik Türk şairleri tarafından kullanılmış, birer gözlem nesnesi olarak şiirde yer almıştır. ${ }^{24}$ Estetik algının bir parçası hâline getirilemeyeceği dü-

22 İrvin Cemil Schick, Bedeni, Toplumu, Kâinatı Yazmak: İslâm, Cinsiyet ve Kültür Üzerine, Yay. Haz. Pelin Tünaydın, İstanbul, İletişim Yayınları, 2011, s. 12.

23 Schick, a.g.e., s. 9.

$24 \mathrm{Bu}$ makalenin konusu olmamakla beraber, doğal çiçeklerin kitap sanatlarında kullanımlarına dair Yıldız Demiriz'in sunduğu kronolojiyi burada anmakta fayfa var: Demiriz'in verdiği tabloda toplamda otuz altı çiçek kendine yer bulabilmiştir. Çiçeklerin kitap süslemesinde ilk defa kullanıldığı yüzyıl olarak on altıncı yüzyılla, tarih olarak da 1546 ile karşılaşmaktayız. Söz konusu çiçekler kitap sanatlarında tarihî açıdan kullanılma önceliklerine göre şunlardır: Haşhaş, gül hatmi, çuha çiçeği, bahar açmış meyva ağacı, kokulu menekşe, çiğdem, zambak, calendula, süsen, lale, karanfil, sümbül, manisa lalesi, gül, zerrin, siklamen (buhur-1 Meryem), şebboy, ağlayan gelin, hercai menekşe, hezaren, kadife çiçeği, Cezayir menekşesi, erguvan, salkımlı sümbül, bahçe açelyası, nerengül (katmerli düğün çiçeği), Peygamber çiçeği, gelincik, Haseki küpesi, leylak, Kasımpatı, kardelen, sümbülbeter, çanta çiçeği, şakayık, düğün çiçeği (yalınkat). Bkz. Yıldız Demiriz, Osmanlı Kitap Sanatlarında Doğal Çiçekler, İstanbul, Yorum Sanat, 2005, s. 291. Aynı yazarın daha önceki bir çalışmasında çiçek sayısının otuz bir olarak tespit edildiğini de belirtmekte fayda var. Bkz. Yıldız Demiriz, Osmanlı Kitap Sanatında Natüralist Üslupta Çiçekler, İstanbul, İstanbul Üniversitesi Edebiyat Fakültesi Yayınları, 1986, s. 376. 
şünülen çiçekler ise dışarıda bırakılmıştır. Aşağıda klasik Türk şiirinde kullanılan çiçekler tek tek sıralandığında da görüleceği gibi şairler estetik anlam yüküne sahip çiçeklere şiirlerinde yer vermeyi tercih etmişlerdir. "Şu hâlde taranan dîvânlarda tespit edilen çiçek sayısı ilk bakış̧a 19'dur. Ancak çiçeklerle ilgili değişik adlandırmalar ve bu çiçeklerin değişik türleri dikkate alındı̆̆ında bu sayı 28'e yükselmektedir." ${ }^{25}$ Klasik Türk şiirinde kendilerine yer bulmuş çiçekler şunlardır:

"[K]lasik Türk şiirinde isimleri bizzat zikredilmek suretiyle, geçen 28 çiçek şöyledir: gül (verd), nesrîn, nesteren; lâle, şakâyıku'n-nu'mân; sünbül; nergis, ('abher), zerrîn, zerrîn-kadeh; nevrûz; benefşe (menevşe); yâsemin (semen, yâsemen); sûsen; nilûfer (nîlû-per, nîlû-berg), çadır çiçeği; reyhân, fesleğen; karanfil (karanfül); za'ferân; şebbû (şebbûy); zanbak; buhûr-1 Meryem, bahûr-1 Meryem; leylâk; merzengûş (mercanköşk), sedâb, lisânü’s-sevr."26

Her ne kadar sayı yirmi sekiz gibi görünse de aynı çiçeğin farklı isimlerini listeden çıkardığımızda elimizde on dokuz çiçek kalmaktadır. ${ }^{27}$ Kitap sanatlarında çiçeklerin kullanımıyla ilgili Demiriz'in verdiği tabloya göre otuz altı çiçek kullanılmıştır. ${ }^{28} \mathrm{Bu}$ veriden şu iki sonuca varılabilir: Osmanlı devrindeki şairlerin âşina oldukları çiçek sayısı on dokuzdan fazladır ve kimi çiçekler klasik Türk şiiri içinde kendilerine yer bulamamışlardır. Demiriz ${ }^{29}$ ve Bayram ${ }^{30}$ tarafindan sunulan verileri mukayese ettiğimizde, kitap sanatlarında kullanıldığ 1 halde klasik Türk şiirinde kullanılmamış çiçek türleri şunlardır: Haşhaş, gül hatmi, çuha çiçeği, bahar ${ }^{31}$ açmış meyva ağacı, çiğdem, calendula, ağlayan gelin, hezaren, kadife çiçeği, açelya, nerengül (katmerli düğün çiçeği), Peygamber çiçeği, Haseki küpesi, Kasımpatı, kardelen, sümbülbeter, çanta çiçeği, yalınkat.

Osmanlı devri şairleri için gözlem önemli olmakla beraber gözlemlenenin estetik hususiyeti daha büyük önemi haizdir. Nitekim yukarıda sayılan çiçeklerin tümünü muhtemelen görmüş olan Nâbî'nin Dîvân'ında teşbih unsuru olarak çiçeklerin incelendiği bir çalışmada sadece şu çiçeklere tesadüf edilmiştir: Gül, gonca, sümbül, lâle, nergis, yasemin, nilüfer, benefşe, sûsen, erguvan, nesteren,

25 Bayram, "Duygularin Dili ...", s. 216.

26 Bayram, "Duygularin Dili ...”, s. 217.

27 Gül ü Bülbül, Gülşen-âbâd gibi, çiçekleri de birer hikâye kahramanı olarak kullanan eserlerde de benzer çiçekler rol almıştır. Her ne kadar elimizde böylesi bir istatistik olmasa da mesnevi ve diğer hikâyelerin taranması sonucu çiçek sayısının pek artmayacağı kanaatini taşımaktayız.

28 Demiriz, Doğal Çiçekler, s. 291.

29 Demiriz, Doğal Çiçekler s. 291.

30 Bayram, "Duygularin Dili ...", s. 217.

31 Demiriz, "bahar" kelimesini çiçek anlamında kullanmaktadır. Bkz. Demiriz, Doğal Çiçekler, s. 274. Bahar kelimesi klasik Türk şiirinde yaygın bir şekilde çiçek anlamında kullanılmaktadır. Bu konu hakkında geniş bilgi için bkz. Ozan Yılmaz, "Klasik Türk Edebiyatı'nda Bir Başka Anlamıyla 'Bahar”, Ankara Üniversitesi Dil ve Tarih-Coğrafya Fakültesi Türkoloji Dergisi, say1 18, 2011, s. 184-186. 
zanbak-nesrin ve karanfil. ${ }^{32}$ Yukarıda dile getirildiği gibi şehirlerde gözlemlenebilen, bahçelerde yetiştirilen söz konusu çiçekleri kullanım sıklığına göre incelediğimizde/sıraladığımızda aşağıdaki gibi bir sonuçla karşılaşmaktayız. ${ }^{33}$

\section{Gül}

Klasik Türk şiirinde en sık kullanılan çiçek şüphesiz güldür. ${ }^{34}$ Gül, daha çok sevgiliyle birlikte düşünülmüş; aynı zamanda peygamber efendimizin göstereni olarak şiire konu edilmiştir. "Yûnus Emre'nin, 'Çiçek eydür ey derviş gül Muhammed teridir' mısraında ifade ettiği gibi gülün kokusunu Resûl-i Ekrem'in terinden aldığına inanılır. Halk arasında, 'Gül koklamak sevaptır' sözü de daha çok bu çiçeğin Hz. Peygamber'in sembolü olmasından kaynaklanmaktadır." 35 Gülün Peygameber teri olmasının ardındaki hikâye şudur: "Yüce Peygamber'in, Cenâb-ı Hakk'ın huzuruna vardı̆̆ı Mi'râc gecesi vuku bulan hâdiselerin ăğırlığ karşısında; Hz. Peygamber, Cebrâil ve Burak'ın terler döktüğ̈̈ ve Burak'ın terinden yeryüzünde sarl gül, Cebrâil'in terinden beyaz gül, Hz. Peygamber'in terinden kırmızı gülün hâsıl olduğu rivâyet edilir." ${ }^{36}$

Yavuz Bayram, klasik Türk şiirinde çiçeklerin kullanım sıklıklarını istatistiksel veriler ışığında değerlendirdiği çalışmasında şöyle bir sonuca varır:

"Klasik Türk şiirinde en çok dikkat çeken çiçek, tartışmasız gül olmuştur. Gülden sonra divan şairlerinin en çok kullandıkları çiçekse lâledir. Sümbül, nergis, yâsemin ve menekşe de klasik Türk şiirinde oldukça sık kullanılan çiçeklerdendir. Kullanıldıkları beyitlerin sayıları açısından dördüncü grubu; reyhân, sûsen, erguvân, karanfil, nilüfer, şebboy, za'ferân ve zambak oluşturmaktadır. Buhurımeryem, leylâk ve mercanköşk gibi çiçeklerin geçtiği beyitler ise istisna derecesinde azdir." ${ }^{37}$

Gül aynı zamanda, sevgilinin yanağı, yüzü, dudağı; kimi zaman şarap ve kadeh olarak da beyitlerde kullanılmıştır. Bunun nedeni gülün renk, şekil ve koku açısından sevgilinin mezkûr uzuvlarına teşbih edilmesidir. Şekil itibariyle yüz, renk itibariyle yanak ve dudak ile müşabehet ilişkisi içinde olan gül, şekil bakımından kadeh, koku ve renk açısından da şarapla ilişki içinde düşünülmeye müsaittir. Bunların yanı sıra, "Sadece Necatî Bey, Hayâlî Bey, Fuzûlî ve Nev'î̀nin

32 Esra Öner, Nâbî Dîvânı'nda Teşbih Unsuru Olarak Çiçekler, Yayımlanmamış Yüksek Lisans Tezi, İstanbul, Fatih Üniversitesi Sosyal Bilimler Enstitüsü, 2004, s. 55-96.

33 Makalede her bir çiçeğe klasik Türk şiirindeki kullanım sıklığı nispetinde yer vermeye özen gösterdik.

34 Gülün Arap ve Fars edebiyatlarındaki kullanımları için bkz. Nezahat Öztekin, "Eski Türk Edebiyatında Gül”, Kubbealtı Akademi Mecmuası, sayı 34/4, 2005, s. 21-27.

35 Cemal Kurnaz, "Gül”, TDV İslam Ansiklopedisi, cilt 14, 1996, s. 220.

36 Emine Yeniterzi, Divan Şiirinde Na 't, Ankara, Türkiye Diyanet Vakfı Yayınları, 1993, s. 274.

37 Bayram, “Duygularin Dili ...”, s. 217-8. 
gül kasideleriyle Bâkî'nin gül redifli beş gazeli bile çiçekler sultanının eski edebiyatımızda ne kadar zengin bir hayal dünyası yarattığını göstermeye yeter." 38 Gülün dîvânlarda ne kadar sık kullanıldığına bir örnek olarak ${ }^{39}$ İlyas Yazar'ın Necatî Bey Dîvânı'nda “gül”"lü kullanımları araştırdığı makalesine bakıldığında şöyle bir tabloyla karşılaşırız: "Divanda yer alan 650 gazelden 255 'inde gül ve güle dair çağrışımlara yer verilmişs olup gülün kullanıldı̆̆ 255 gazelde toplam 363 beyitte güllü kullanım formları tercih edilmiştir." 40

Gülün yukarıda zikredilen estetik hususiyetlerinin yanı sıra şairlerce kabul görmesinin bir diğer nedeni de gül-bülbül ilişkisi içinde ve âşığın göstereni bülbüle karşılık sevgilinin göstereni olarak kullanılmasıdır. ${ }^{41} \mathrm{Bu}$ da gülün klasik Türk şiiri estetiğinin en önemli iki unsurunu yani âşı ve mâşuku açıklamakta ve anlatmakta önemli bir görev icra ettiğinin göstergesidir. Kara Fazlî’nin Gül $\ddot{u}$ Bülbül adlı meşhur mesnevisinde gülün başka bir kullanımıyla karşılaşırız. Betül Sinan Nizam'a göre mesnevide gönül (Bülbül), ruha (Güle) kavuşmaya çalışır. $\mathrm{Bu}$ da aslında gönlün kemâle, mükemmel birliğe ulaşma arzusudur. Bülbül ve Gül'ün hikâyenin sonunda kavuşması, seyr ü sülûkün birlikle sonuçlandığını, sâlikin iç tekâmülünü tamamladığını gösterir. ${ }^{42}$

Klasik Türk şiiri estetiği içinde gül, heyet olarak maşukun müşebbehi vazifesini ifa etmektedir. Gülün boyu ile sevgilinin boyu, gülün rengi ile sevgilinin yüzü ve yanakları, gülün nazlı yapısıyla sevgilinin nazı, gül-i ra'na ile sevgilinin hem âşı hem de rakibe yüz veren mizacı, bahar mevsiminde gülün açılmasıyla sevgilinin baharda gezintiye çıkması, gülün üzerindeki çiğ tanesiyle sevgilinin kulağındaki küpe, gülün dikeniyle rakip, gülün yapraklarının kat kat oluşuyla kulak arasındaki ilişki, gülle ilgili önemli estetik hususiyetler olarak dikkat çeker.

38 Ayvazoğlu, Güller Kitabı, s. 99.

39 Gülün kullanımına dair daha derli toplu ve yirmi altı Türkçe dîvânın incelenmesine dayanan istatistikî bilgiler ihtiva eden bir çalışma için bkz. Yavuz Bayram, "Burdur'un ve Divanların Gülü”, I. Burdur Sempozyumu, 16-19 Kasım 2005, Burdur, Mehmet Akif Ersoy Üniversitesi Rektörlüğü Yayınları, 2007, s. 368-386.

40 İlyas Yazar, "Necâtî Bey’in Gazellerinde Açan Çiçeklerin Sultanı 'Gül”, Turkish Studies, 2009, say1 4/8, s. 2371)

41 Necâtî, Hayâlî ve Fuzûlî’nin “gül”” redifli kasidelerinin Ebû Temmâm'1n (ö. 845) bir kasidesiyle karşılaştırılıdığı ve Arap kasidesiyle Osmanlı dönemi kasideleri arasındaki süreklilikleri araştıran bir makale için bkz. Yorgos Dedes-Stefan Sperl, "Her varak bir nüktedür gülşende': üç Osmanlı kasîdesine Arap kasîdesi açısından bir bakış", Eski Türk Edebiyatı Çalışmaları VIII: Kasîdeye Medhiye: Biçime, Işsleve ve Muhtevaya Dair Tespitle, Haz. Hatice Aynur vd. İstanbul: Klasik Yayınlar1, 2013, s. 188-239.

42 Betül Sinan-Nizam, "Divan Şiirinin Alegorik Âşık ve Maşuklarından Gül ü Bülbül”, Turkish Studies, 2010, say1 5/3, s. 472 . 


\section{Lâle}

Klasik Türk şiirinde ilk zamanlarda taşralı bir çiçek addedilen lâle, estetik bir unsur olarak kabul gördükten sonra en çok kullanılan çiçeklerden biri olmuştur. Necâtî'nin yüz doksan sekizinci gazelinde yer alan "Taşradan geldi çemen mülkine bîgâne diyü/Devr-i gül sohbetine lâleyi iletmediler" 43 şeklindeki meşhur ikinci beyti lâlenin on beşinci yüzyılda henüz bahçelerde yetiştirilmediği şeklinde yorumlanabileceği gibi klasik Türk şiiri estetiğine dâhil edilmediğini de gösteren bir beyit olarak telakki edilebilir. Yine de lâle hem klasik Türk şiirinde kullanımı hem de hakkında yapılmış çalışmalardan dolayı gülden sonra anılmayı hak eder.

"Gülden sonra klasik Türk şiirinde en sık rastlanan çiçek lâledir... Ayrıca ilişkilendirildiği şahıslar arasında 'sevgili ve güzel', uzuvlar arasında 'yanak ve dudak', eşyalar arasında 'kadeh ve şarap', doğal ve kozmik öğeler arasında 'güneş, ay ve ateş', soyut kavramlar arasında da başta şiirsel terimler olmak üzere olumlu anlam ve çağrışım ifade edenler daha çok dikkat çekmektedir." ${ }^{44}$

Lâle hakkında müstakil bir eser kaleme alan Ayvazoğlu'na göre “ilk laleler başlarını muhtemelen Orta Asya'da, Tiyenşan Dağları'nın kuzey yamaçlarında güneşe uzattılar." ${ }^{45}$ Yazara göre lâleler önce İran şiirinde kullanılmışlardır. Özellikle Hayyam, Hâfiz ve Sadî’nin şiirlerinde ilk defa lâle isimlerine rastlanmaktadir ${ }^{46}$. Bu çiçeğin Türk şiirine intikali ise Mevlana sayesinde olmuştur. "Anadolu'da şiirin mecaz dünyasına Mevlânâ'nın şiirleriyle birlikte giren lâle, Türkçe şiirde XIV. yüzyllda uç verdi ve önce Ahmedî'nin şiirlerinde yüzünü utangaç bir eda ile göstermeye başladı." ${ }^{47}$ Lâlenin klasik Türk şiirinde kolayca benimsenmesi ve sıkça kullanılmasının sebeplerinden birisi de lâle kelimesinin ve Allah lafzının aynı harflerle yazılmasıdır. Tabîb Mehmed Aşkî, Ayvazoğlu'nun ${ }^{48}$ aktardığı şu beytinde yukarıdaki düşünceyi dile getirmektedir:

Mazhar-1 ism-i celâl olmasa âyâ lâle

Bulamazdı bu kadar rütbe-i vâlâ lâle

Lâlenin ortaya çıkışıyla ilgili birkaç rivayet vardır. Bunları Yakup Poyraz şöylece özetlemektedir:

"Mitolojide lale güneş ve bitki tanrısı olarak anılan Adonis can verdiğinde bedeninden süzülen kanlar ile sulanan toprakta yeşermiş bir çiçek olarak tanım-

43 Ali Nihat Tarlan, Necati Beg Divanı, İstanbul, M.E.B., 1997, s. 298.

44 Bayram, "Duygularin Dili ...", s. 212.

45 Beşir Ayvazoğlu, Ateş Çiçeği Lale, İstanbul, İstanbul Büyükşehir Belediyesi Kültür İşeri Daire Başkanlığı, 2003, s. 2.

46 Yine de lâle kelimesinin ilk zamanlarda günümüzde "gelincik" adı verilen çiçek için kullanıldığını hatırlamak yerinde olur.

47 Ayvazoğlu, Ateş Çiçeği Lale, s. 4.

48 Ayvazoğlu, Ateş Çiçeği Lale, s. 7. 
lanmaktadır. İran mitolojisinde ise lale, üzerindeki çiğ tanesine düşen yıldırım sonucu yaprağının alev alması ve o anda donup kalması sonucu göbeğindeki siyah lekeye (yıldırımdan kalan yanık izi) sahip olmuştur. Hristiyanlıkta ise, Hz. İsa çarmıha gerildiğinde annesi Hz. Meryem'in döktüğü gözyaşlarının toprağa döküldügüü yerde yeşermiş bir çiçek olduğuna inanılmaktadır. Bu sebeple lale (ters lale) aynı zamanda Hz. Meryem'i de simgelemekte olan bir çiçektir." ${ }^{49}$

Lâle yetiştiriciliği Osmanlı topraklarında sonradan rağbet görmüştür. "İstanbul'da islah edilmiş lâleyi ilk olarak yetiştiren, Tabib Mehmed Aşkî Efendi'nin Takvîmü'l-kibâr ve Mi'yârü'l-ezhâr adlı eserine göre, Kanûnî'nin şeyhülislâmı Ebussuûd Efendi'dir (1491-1574)"50 Bu devirden sonra özellikle Lâle devri ve öncesinde lâle yetiştiriciliği Osmanlı topraklarında çok revaç bulmuştu. Dolayısıyla bu dönemde "Lâle isimleri mütemâdiyen değişmektedir." Yeni bulunan lâlelere yeni isimler veriliyor ve kimi şairler de bu isimleri şiirlerinde kullanıyorlardı. Nedîm, yeni yetiştirilmiş lâle isimlerinden biri olan "ferah-engîz"i bir beytinde kullanmıştır:

Hemîşe bu müferrih lâle-i dil-cûy-1 hüsn-âmiz

Ola ismi gibi bezm-i şehenşâha Ferah-engîz ${ }^{52}$

Klasik Türk şiir estetiği içinde kendine muhkem bir yer edinmiş olan lâle, çoğunlukla renginden ve şeklinden dolayı teşbihlere konu olmuştur. Örneğin Hayâlî Bey Dîvânı'nda “renginden dolayı âşık, gönül, kan, yara, yüz, yanak, gelin, kanlı göz ve göz yaşı, kanlı kefen, ateş, çeră̆, şafak, şarap" gibi unsurlara teşbih edilmişken "şeklinden dolayı kadeh, çadır, asker, sancak beyi, kırmızı fânûs, etfâl, külâh, dil" ${ }^{53}$ gibi unsurların müşebbehi olarak kullanılmıştır. Bazen lâle ve elif harfi arasında da ilişki kurulduğuna rastlanmaktadır. Bu durumda lâle, sevgiliyi/Allah'ı temsil eden bir kavram halini almaktadır. Âşığın gönlü de lâle gibi kırmızıdır çünkü aşktan dolayı yanmıştır. Lâlenin ortasındaki yanık ile âşığın yanık gönlü arasındaki müşabehet de lâlenin söz konusu estetik hususiyetini takviye etmektedir. Kadeh ve içindeki şarap, lâlenin hem şekil hem de renk açısından çokça kullanılan iki hususiyetini kendinde cem etmiş bir hayal olarak şiirde kendine yer bulmuştur.

49 Yakup Poyraz, "Blossoming of the Love: Flowers and Love in the Ottoman Poetry", IIB International Refereed Academic Social Sciences Journal, 2014, say1 15, s. 329.

50 Sevda Önal, "Klasik Türk Edebiyatında Lâle ve Edebi Bir Tür Örneği Olarak Lâle Şiirleri”, Turkish Studies: International Periodical for the Languages, Literature and History of Turkish or Turkic, say1 4/2, 2009, s. 912.

51 Ekrem Hakkı Ayverdi, 18. Asırda Lâle, Haz. M. Uğur Derman, İstanbul, Kubbealtı Neşriyat, 2006, s. 15.

52 Ayverdi, a.g.e., s. 15.

53 Cemal Kurnaz, Hayâlî Bey Divânı'nın Tahlîli, İstanbul, M.E.B., 1996, s. 541. 


\section{Sünbül}

Klasik Türk şiirinde gül ve lâleden sonra en sık kullanılan çiçeklerden biri olan sünbülün "[k]lasik Türk şiirindeki temel işlevi; sevgilinin saçı, zülfüu, kâkülü vs. için doğal bir benzetmelik öğesi olarak değerlendirilmesine dayanır" ${ }^{\prime 4} \mathrm{Sev}-$ gilinin saçına, zülfüne ve kâkülüne benzetilmesinin nedeni koyu rengi ve güzel kokusudur. Sünbülün İstanbul'dan Avrupa'ya giden bir çiçek olduğu düşünülmektedir.

“Islah edilmiş sümbül melezlerinin Avrupa'ya ilk kez İstanbul'dan gönderildikleri biliniyor. Bu bitkilerin, lâle çılgınlığının Hollanda'da bir krizle sonland1ğ1 ve lâle zenginlerinin bir bir iflâs ettikleri dönemde Avrupa'da lâlenin yerine geçtiğini ve ön plana çıktığını görüyoruz. Bizde ise, hiçbir zaman gül ve lâlenin önüne geçemeseler de, XV. yüzyıldan itibaren şiirimizin, süsleme sanatlarımızın ve bahçelerimizin en gözde 4 çiçeği arasında görüyoruz sümbülleri." ${ }^{55}$

Sabiha Tansuğ'un metnini, İngilizce çevirisiyle beraber yayımladığı Sümbül-nâme, söz konusu çiçeğin ne kadar sevildiğini gösteren önemli bir eserdir. Sümbül-nâme, 1736'da kaleme alınmış ve Hıfzî, Salahî ve Çuhadar Hüseyin adlı üç şairin şiirlerini ihtiva etmektedir. ${ }^{56}$ Çiçekler konusundaki çalışmalarıyla tanınan Cevat Rüştü de sümbülün yerli bir çiçek olduğu kanaatindedir: "Bizde dahi sümbülün lâle ve zerrin gibi millî çiçekler arasında bulunduğuna şüphe yoktur. Hatta Şükûfe-nâme sahibi Ali Çelebi merhum bu çiçeği millî çiçeklerimiz arasında ta'dat ettiği gibi, bu hususta irae ettiğimiz tarihî tedkikât da Çelebi merhumu tasdik ve teyit ediyor." 57

Sünbül redif olarak da uygun bulunmuş olmalıdır ki şairler "sünbül” redifini sıkça kullanmışlardır. Yaşar Aydemir'e göre "kasidelerde redif olarak bitkiler içerisinde 'gül'den sonra en çok işlenen konu sünbül'dür. ${ }^{58}$ Sünbülün şiire konu olan özelliklerinden birini de Gülay Karaman aktarmaktadır:

"Çiçekleri üzerinde hem erkek hem dişi organlar bulunduğu için sünbülün tohum yapabilme olasıllı̆ı yüksektir. Dolayısıyla sünbül, tohumları bol olan bir bitkidir. Bâkî, sünbülün her yıl tohumlarını artırdığına dair halk arasında var olan bir düşünceyi şöyle dile getirir:

54 Bayram, "Duygularin Dili ...”, s. 213.

55 Gürkan Ceylan, Osmanlı'dan Günümüze Dört Gözde Çiçek: Güller, Karanfiller, Lâleler ve Sümbüller, İstanbul, Flora Yayıncılık, 1999, s. 104.

56 Tansuğ, Sabiha, Türklerde Çiçek Sevgisi ve "Sümbülname”, İstanbul, Ak Yayınları, 1998, s. 56.

57 Cevat Rüştü, Türk Çiçek ve Ziraat Kültürü Üzerine Cevat Rüştü'den Bir Güldeste, Haz. Nazım Hikmet Polat, İstanbul, Kitabevi Yayınları, 2001, s. 169.

58 Yaşar Aydemir, "Sünbüliyye", Türk Dünyası Ortak Edebiyatı Türk Dünyası Edebiyat Kavramları ve Terimleri Ansiklopedik Sözlüğ̈̈, cilt 5, Ankara, Atatürk Kültür Merkezi Başkanlığı Yayınlar1, 2006, s. 358. 
N'ola kadr ü şerefün sâl-be-sâl olsa mezîd

Her y1l arturmadadur dâneyi dirler sünbül" ${ }^{19}$

Klasik Türk şiiri estetiği açısından sünbül; renk, koku ve şekil boyutlarıyla önem arz etmektedir. Koyu rengi ve kokusu açısından saç ve kâkülle ilintili olarak düşünülmüştür. Şekil açısından ise dağınıklık ve perişanlık mefhumlarını anımsattığından dolayı, dağınık saçın benzetileni olarak şiirimizde estetik bir kullanım olarak kendine yer bulmuştur.

\section{Nergis}

Klasik Türk şairleri herhangi bir nesnenin dişsal özelliğine uygun, gerçekçi benzetmeler kurarlar. Aynı ilke nergis için de geçerlidir. Nergis, şekil ve renk bakımından göze benzediği için daha çok sevgilinin gözüyle teşbih ilişkisi içinde kullanılır. "[Nergis] hasta, sarhoş ve âşık; eşya arasından tâc, külâh, kadeh, altın ve gümüş; kozmik öğeler arasından da yıldızlar"la birlikte düşünülür. ${ }^{60}$ Nergis ve narsisistik kişilik bozukluğu arasındaki ilişki bilinmektedir. Ayvazoğlu, bu ilişkinin hikâyesini şu şekilde anlatmaktadır:

"Mitolojiye göre, Narkissos öldükten sonra sarı göbeğini beyaz yaprakların kucakladığı bir çiçeğe dönüşmüştür: Nergis. Bu efsaneden gelen 'narsisizm' terimi, psikolojide 'kendi kendine hayranlık' diye k1saca tarif edilebilecek bir kompleksin teknik adı olmuştur. Narkoz ve narkotik gibi terimler de aynı kökten gelir. İlgi çekici olan, nergisin bünyesinde uyuşturucu bir maddenin bulunmasıdır. Bunun için divan şairlerine göre nergis bîmardır, mesttir, mahmûrdur. Çiçek toplumunda ise elinden kadehi düşmeyen biri olarak tasavvur edilmiştir." ${ }_{1}$

Klasik Türk şiiri açısından nergisin estetik önemi, beyitlerde onun mitolojik kökenine de vurgu yapılmak yoluyla telmihe konu olması ve gözle ilişkisinden dolayı şiire kattığ 1 estetik hususiyet olarak zikredilebilir. Bu yüzden divanlarda maşukun mestâne, mahmur, sâhir bakışı; âşıkın hasta, uykusuz bakışı nergisle temsil edilebilir. Ahmet Paşa'nın şu beyti nergis, mest ve uyku ilişkisine güzel bir örnektir:

Çeksün müdâm nergis-i mestüm şarâb-1 nâz

Kim geldi hüsn bezmine mahmûr-1 hâb-1 nâz ${ }^{62}$

Ahmedî’nin şu beytinde çiçek, sevgili ve klasik Türk şiiri estetiğini muhtasar bir şekilde bir arada görmek mümkündür. Aynı zamanda yukarıda sözü geçen lâle, sünbül ve nergis de bir arada kullanılmıştır:

59 Gülay Karaman, "Perîşân Çiçek Sünbül ve Klasik Türk Şiirinde İşleniğì", İnsan ve Toplum Bilimleri Araştırmaları Dergisi, sayı 1/2, 2012, s. 315.

60 Bayram, "Duygularin Dili ...", s. 214.

61 Ayvazoğlu, Güller Kitabı, s. 142.

62 Harun Tolasa, Ahmet Paşa'nın Şiir Dünyası, 2. Bs., Ankara, Akçağ, 2001, s. 481. 
Bu ne yüzdür bu ne gözdür bu ne zülf ü bu ne bâlâ

Biri lâle biri nergis biri sünbül biri tûbâ ${ }^{63}$

\section{Yasemin}

Klasik Türk şiirinde yaseminle birlikte "uzuvlar arasından saç, zülf, yanak ve sînenin; eşya arasından elbise, altın ve gümüşün; şahıslar arasından da sevgili ve güzelin daha çok dikkat çektiği anlaşılmaktadır." ${ }^{4}$ Es'ad Efendi'nin aşağıdaki beyti yasemin ve sevgilinin bedeni arasındaki ilişkiyi göstermekte, renk açısından bir teşbih ilgisi olduğunu ortaya koymaktadır:

Fem gonça turre sünbül ü had lâle kad nihâl

Ruhsâr verd-i âl ü beden yâsemîn ola (Es'ad Efendi K 7/9) ${ }^{65}$

Yasemin daha çok rengi dolayısıyla şiire konu olmuş görünmektedir. Onun bu estetik hususiyeti sevgilinin yanak, sine, gerden ve heyet olarak bedenine teşbih edilmesini beraberinde getirse de Neşâtî'nin aşağıdaki beytinde de görüldüğü gibi beyaz olan sarığa da benzetildiği olmuştur:

Yâsemeden ser-zede sünbül sanır seyr eyleyen

Gûşe-i destârdan kim zülf-i 'anber-bû çıkar ${ }^{66}$

Aktarılan örnek beyitlerden de anlaşıldığı üzere yaseminin estetik açıdan daha çok öne çıkan yönü rengidir. Bu da, beyitlerde beyazlık olarak tebarüz etmiş görünmektedir.

\section{Menekşe}

Klasik Türk şiiri estetiği içinde kendine yer bulan çiçeklerden menekşe, baş1 eğik olduğundan klasik Türk şiirinde daha çok âşık için bir benzetmelik olarak kullanılmaktadır. Menekşenin âşığın müşebbehi olarak kullanılıyor oluşunun nedenlerinden bir diğeri de bu çiçeğin zayıflığıyla aşığın bedeninin zayıflı̆̆ı arasında kurulan ilişkidir. Âşık, çektiği eza ve cefalardan dolayı bedenen zayıf düşer. Menekşe de incecik bedeninin zayıflı̆̆ından dolayı her an yerinden çıkacakmış gibi bir izlenim bırakır bakan kişide. İlk dönem şairlerinden Ahmedî'nin şu beyti boynu bükük âşık ve menekşe arasındaki benzerlik ilişkisini göstermektedir:

Senüñ zülfüne boynın ege gitdi

Benefşe nite kim 'Azrâya Vâmık ${ }^{67}$

63 Yaşar Akdoğan, Ahmedî Dîvânından Seçmeler, Ankara, Kültür ve Turizm Bakanlığı Yayınları, 1988, s. 86.

64 Bayram, "Duygularin Dili ...", s. 214.

65 Muhammet Nur Doğan, Şeyhülislam Es 'ad ve Dîvânı, İstanbul, M.E.B., 1997, s. 60.

66 Ahmet Talat Onay, Açıklamalı Divan Şiiri Sözlüğü, haz. Cemal Kurnaz, Ankara, Birleşik, 2007, s. 342.

67 Melike Erdem Günyüz, Ahmedî Divanı'nın Tahlili, Yayımlanmamış Doktora Tezi, İstanbul, İstanbul Üniversitesi Türkiyat Enstitüsü, 2001, s. 188. 
Menekşenin aynı zamanda maşukun zülfü veya kâkülü için de bir teşbih unsuru addedildiği görülmektedir. ${ }^{68}$ Buradaki benzerlik ilgisi menekşenin koyu rengidir. Zülf ve kâküle benzer şekilde sevgilinin ben'i ve ayvatüylerine de teşbih edildiğine rastlanmaktadır. "Ben ile ilgili olunca, benin yüz üzerinde oluşu ve yüzgül münasebeti dolaylsiyla menekşe, ekseriyetle gül ile birlikte hayallere konu olur." ${ }^{69}$ Harun Tolasa'nın Ahmet Paşa Dîvânı'ndan aktardığı şu beyit menekşe ve ayvatüyleri ilişkisini ortaya koymaktadır:

Bitürdi nigârun yüzi gül-zârı benefşe

Olsa yaraşur taze gülün yârı benefşe $\mathrm{e}^{70}$

Menekşenin renk açısından; zülf, kâkül, ben gibi sevgiliye ait hususiyetlerle kurduğu müşabehet ilişkisi onun koku olarak miskle beraber anılmasını da sağlamıştır. Dolayısla estetik olarak menekşe; şekil, renk ve koku gibi hususiyetler bakımından sırasıyla boynu bükük ve bedeni zayıf âşı, her biri koyu addedilen sevgilinin zülf, kâkül ve beni ve son olarak miskle beraber anılmak yoluyla şiirde kendine yer bulmuştur. ${ }^{71}$

\section{Reyhân}

Siyah rengi ve kokusu dolayısıyla sevgilinin saçı, zülfü, kâkülü ve yanağındaki ayva tüyüne benzetilen çiçeklerin sayısı çoktur. Bunlardan biri de reyhândır. Burada da teşbih ilişkisi esnasında renk ve koku işlevlerinin ön planda olduğu göze çarpmaktadır. Teşbih ilişkisindeki koku unsurunun çok güçlü bir şekilde işlenmiş olmasına dikkat çeken Bayram'a göre Mesîhî'nin aşağıdaki beyti gibi kimi beyitlerde reyhan "attar" anlamına gelecek şekilde kullanılmaktadır:

Solmamaya sünbül-i zülfün sifâl-i sînede

Su seper reyhâncı gibi dîde-i giryân ana ${ }^{72}$

68 Bayram, "Duygularin Dili ...", s. 215.

69 Tolasa, Ahmet Paşa, s. 477.

70 Tolasa, Ahmet Paşa, s. 477.

71 Menekşe her ne kadar şiirde gül ve lâle kadar sık kullanılmamış olsa da ilk dönem şairlerinden Necâtî'nin ona ayrı bir önem verdiği anlaşılmaktadır. Nitekim Necâtî, Sultan Mahmut'a sunduğu bir kasidesine "Kaside-i Benefşe der-Medh-i Sultân Mahmûd" ismini vermiştir. Toplamda kırk yedi beyitten oluşan kasidenin ilk ve son beyitleri Necâtî’nin menekşeye çiçekler arasında uygun gördüğü rütbeyi gösterir niteliktedir:

Gülşende re'îs olmaga ezhâra benefşe

Demdür ki kadem-rence kılavara benefşe

Hakdan dilerem devlet-ü-'ömrüñ ola câvid

Nite kim ola pîş-rev ezhâra benefşe

Bkz. Ali Nihat Tarlan, Necati Beg Divanı, İstanbul, M.E.B., 1997, s. 87-90.

72 Yavuz Bayram, Çiçeklerle Diğer Bitkilerin Dîvân Şiirine Yansımaları ve Anlam Çerçeveleri, Yayımlanmamış Doktora Tezi, Samsun, Ondokuz Mayıs Üniversitesi Sosyal Bilimler Enstitütüsü, 2001, s. 575. 
Tolasa, Ahmet Paşa Dîvânı'nda yer alan aşağıdaki beyte dikkatimizi çekmektedir:

Gül yüzünde hatt-1 reyhânun ki cân hayrânudur

Nâme-i tezvîrdür ben dutmazam anı dürüst ${ }^{73}$

Bu beyitte Tolasa'nın da belirttiği gibi reyhanın sıkça kullanılan diğer iki estetik hususiyeti öne çıkmaktadır. Bunlardan biri reyhan kelimesinin aynı zamanda "hatt-1 reyhân̂”"yi çağrıştırması, dolayısıyla beyitlerde reyhan ve sevgilinin ayvatüyleri arasında kurulan benzetmedir. İkincisi de hattın uyandırdığı hayranlığ da içinde barındırmakla beraber reyhan ve hayran kelimelerinin cinas-1 nakıs oluşturmasıdır.

\section{Sûsen}

Klasik Türk şiirinde sıkça karşımıza çıkan bir diğer çiçek sûsendir. "[D]ivan şairleri, sûsenle daha çok kılıç, tîğ, hançer ve şemşî̀r gibi keskin eşya ile ayrıca dil (zeban) ve asker gibi öğeler arasında ilgi kurmuşlardır." 74 Bayram'a göre Hayâlî Bey, Nev'î, Bâkî, Mesîhî gibi şairler sûsene en çok yer veren şairlerdir; aynı şekilde klasik Türk şiirinin usta şairleri bu çiçeği daha sık kullanmayı tercih etmişlerdir. ${ }^{75}$ Klasik Türk şiirinde sûsen, şekil açısından diliyle bağlantılı hayallere konu olmuşken renginden dolayı da sevgilinin zülfüyle ilgili benzetmelerde kullanılmıştır.

Bize çâk-i girîbânın iñen 'arz itmesün sûsen

Kazâ tîgıyla ey Emrî ezelden sîne-çâküz biz (Emrî G 215/5) (6 $^{76}$

Emrî’nin yukarıdaki beytinde tîğ ve süsen ilişkisi ortaya konmuşken aşağıya aldığımız Ahmet Paşa'ya ait beyitteyse süsen, dil ve zülf bir arada kullanılmıştır. Dolayısıyla estetik açıdan süsenin renk ve şekil itibariyle şiire konu olabildiğini söylemek mümkündür.

Sûsen dil uzaduban okur zülfüne senâ

El götürür çınar boyuna du'â içün ${ }^{77}$

\section{Erguvan}

Diğer çiçekler kadar sık kullanılmasa da şekil ve renk açısından şairlere değişik ilhamlar veren bir çiçek de erguvandır. Erguvanın "şarap, kan, kanlı göz yaş1 ve sevgilinin yanağ 1 gibi birbirinden değişik tasavvura malzeme olduğu tespit

73 Tolasa, Ahmet Paşa, s. 479.

74 Bayram, "Duygularin Dili ...", s. 215.

75 Bayram, "Çiçeklerle Diğer Bitkilerin ...", s. 587.

76 Emrî, Emrî Dîvânı, Haz. M. A. Yekta Saraç, İsanbul, Eren Yayıncılık, 2002, s. 135.

77 Tolasa, Ahmet Paşa, s. 481. 
edilmiştir." 78 Bayram erguvan hakkında şunları dile getirmektedir:

"Taç yapraklarının kırmızı, özellikle de eflatun ve eflatunun değişik tonlarında olması, erguvânın divan şairlerince şarapla özdeşleştirilmesine sebep olmuştur. Yine bu bitkisel özelliğinden ilhamla ilişkilendirildiği kadeh, yaş, kan, ateş, dudak, yüz, yanak, yara, yara izi, dil, boy, vücûd, sevgili ve âşık gibi öğeler erguvânın anlam çerçevesini tamamlamaktadır." 79

Bursa' da erguvana has bir bayram kutlandığı kaydedilmektedir. "Evliya Çelebi'nin de 'Erguvan Cemiyeti Faslı' diye söz ettiği bu anlaml gelenek Emir Sultan tarafindan başlatılmıştır." 80 Demirel, söz konusu makalesinde klasik Türk şiirinde erguvan ile ilgili tasavvurlarda şu başlıkların ön plana çıktığını vurgular: "1. Sevgilinin yüzü/yană̆l, 2. Ateş, 3. Aşı̆̆ın kanlı göz yaşl, 4. Kanlı kılıç, ok, 5. Sevgilinin elbisesi, 6. Şarap." ${ }^{\prime 1}$ Nev'î’ye ait olan aşağıdaki iki örnek beyit de aynı makaleden alınmıştır.

Her tarafdan şu'le-sâz oldı nihâl-i ergavân

Bâğa âteş düşdi sandı eyledi bülbül figân (Nev'î, M/1)

Tenüm hûn-1 sirişkümden nihâl-i ergavânîdür

Vücûdum oldı vîrân şehr-i rûyum za'ferânîdür (Nev'î, G-59/1)

Verilen örnek beyitlerden de anlaşıldığı gibi erguvanın estetik hususiyetini daha çok rengi belirlemektedir. Nitekim erguvanla ilgili tasavvurların tümünde renk unsuru diğer özelliklerden daha belirgindir.

\section{Karanfil}

Karanfil, klasik Türk şiirinde az kullanılmakla beraber, birbirinden çok farklı öğelere benzetilmesiyle dikkat çeker. "Diğer taraftan karanfilin anlam çerçevesini; yara (zahm) ve ben (hâl) ile yüz, yanak, boy, göz, çene (zenahdân), zülf, güzel, gelin ('arûs), sevgili, âşık, âbdâl, âbid, kuş ve ylldızlar (encüm) gibi değişik ögeler oluşturmaktadır."

Sûzen-i müjgânı geçdükçe dil-i pür-dâğdan

Sanuram işler harîr üzre karanfil nakşını (Nev'î G 465/4)

Bu beyitle ilgili Nejat Sefercioğlu'nun yorumu şu şekildedir: "Sevgilinin iğneye benzetilen ve beyitte 'sûzen-i müjgân'terkîbiyle yer alan kirpiği, âşı̆ğın ipek

78 Şener Demirel, “Türk Şiirinde Erguvan' Üzerine Bir Deneme”, Uluslararası Türklük Bilgisi Sетроzуити, Erzurum, 25-27 Nisan 2007, s. 5.

79 Bayram, "Duygularin Dili ...”, s. 215.

80 Ayvazoğlu, Güller Kitabı, s. 44.

81 Demirel, a.g.m., s. 8-11.

82 Bayram, "Duygularin Dili ...", s. 215. 
bir kumaş olarak düşünülen yara dolu gönlüne karanfil nakşını işler." ${ }^{83}$ Burada kanlı gönül bir satıh olarak tahayyül edilmiş, kirpik ve iğne arasında uzunluk ve incelik ilgisi kurulmuş; ayrıca karanfil ve kanlı gönül arasında da renk açısından bir benzerlik ilişkisi tasavvur edilmiştir.

Karanfilin de erguvan gibi daha çok öne çıkan özelliği rengi yani kırmızıl1ğıdır. İçinde kullanıldığı beyitlerde ya doğrudan ya da dolaylı olarak kırmızılık, çoğunlukla da âşığın kanı veya kanlı gözyaşı ilgisi bulunmaktadır.

\section{Şebboy}

"[Şebboy] 'Geceleri açması ve güzel kokması' açısından dikkat çekmiş ve bu sebeble en çok 'sevgilinin zülfü ve saçları' yla iliş̧kilendirilmiştir. Ayrıca 'hâl, göz, sûfì ve hırsız' olarak algılanmasında da bu özelliğinin etkili olduğu anlaşılmaktadır ${ }^{84} \mathrm{Bu}$ çiçek, geceleri açtığı için herhangi bir özelliğiyle kara(n)lığı, geceyi, gizliliği çağrıştıran öğelerle birlikte düşünülmüştür. Gece kokusu anlamına da gelen şebbûy kelimesi siyah olan sevgilinin saçlarına, benine, gözüne; geceleri eve girdikleri için hırsıza ve sırrını fâş etmedikleri için bir nevi gizli iş gördükleri

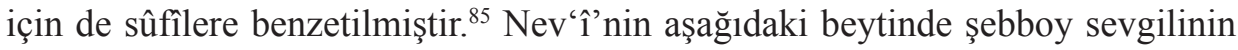
dağınık saçıyla birlikte kullanılmıştır:

Hâl-i rûyın Rûm'da Hind'de disen olmaz ba'îd

Nev'îyâ rûz-1 ruhında zülf-i şeb-bûdır 'aceb ${ }^{86}$

Beyitte yanak ve gündüz bir arada dünüşülmüşken zülf de şeb-bû ile yan yana tahayyül edilmiştir. Bunun sebebi bir yandan yanak ve parlaklık arasındaki ilişkiyken öte yandan zülf, siyahlık, gece ve saçın kokulu oluşu arasındaki katmanlı müşabehettir. Dolayısıyla şebboyun estetik hususiyetini renginden dolayı içinde gizliliği de barındıran siyahlık ve koku olarak belirleyebiliriz.

\section{Za'ferân}

"[Za'ferân] Diğer çiçeklerin aksine sonbaharda açar ve sarı renk elde etmede kullanılır. Bu yönüyle daha çok âşı̆̆ın yüzüyle (çehre, sîmâ, beniz, yanak) ilişkilendirilmiştir." ${ }^{87}$ Yukarıda, erguvan maddesinde aktardığımız beyitte de görüldüğü gibi âş̧ı̆ın yüzü zaferan rengindeymiş gibi tasavvur edilir. Hayâlı̂’nin şu beytinde de benzer bir tahayyüle yer verilmiştir:

83 Sefercioğlu (2001: 443)

84 Bayram, "Duygularin Dili ...", s. 216.

85 Gül ü Bülbül ve Güllşen-âbâd adlı mesnevilerde yer alan çiçekler de şebboyun bu kullanımında olduğu gibi teşhis edilmiş ve çiçeklerin genel özelliklerini yüklenen birer hikâye kişisine dönüştürülmüşlerdir.

86 M. Nejat Sefercioğlu, Nev'î Divanı'nın Tahlîli, Ankara, Akçă̆ Yayınları, 2001, s. 448.

87 Bayram, "Duygularin Dili ...", s. 216. 
Sararmış çihremi sanmam ki reng-i za'ferândur bu

Mahabbet 'âleminde dostum fasl-1 hazândur bu ${ }^{88}$

Za'feranın estetik hususiyetlerinden biri sarı rengiyken diğeri de Harun Tolasa'nın aktardığı gibi tıbbî açıdan "ferahlatıcı ve sevinç verici bir tesirde bulunmasıdır." Tolasa, her iki hususiyeti birden içinde barındıran Ahmet Paşa'nın şu beytini örnek olarak vermektedir:

Yüzüme güldüğüne minnet itme

Ki bu hâssiyetidür za'ferânun ${ }^{89}$

Ahmet Talat Onay, zaferan maddesinde Nâbî' den aldığı bir beyitle onun Nasreddin Hoca'yla bağlantısını kurarak ferahlatıcılığının yanına bir de güldürücülüğün eklemektedir:

"Sarı renkli bir nebâttır. Burhân-ı Kâtı'a göre bulunduğu yere keder gelmez imiş. Asabı tahrik edip ferah verici, güldürücü, hâssayı hâiz olduğunu eski tabîbân ve tıp ulemâsı söylerler. Galiba bunu için düğünlerde zerdeyle pilav vermek âdettir.

Rüy-1 zerdim beste-i leb-bestesin handân eder

Za'ferân nev'-i nebâtın Hace Nasreddîn'idir (Nâbî)"’90

\section{Zambak}

Çağrışım alanı oldukça zengin olmakla beraber nispeten az kullanılmış çiçeklerden biri zambaktır. Zambak, beyazlığ 1 ve zarafetiyle ön plana çıkmaktadır. "Doğal olarak zambağın anlam çerçevesini; güzel, serdâr, yüz, zekân, parmak, yara, kirpik, boy, arz-ı hâl, kef-, Mûsâ, yed-i Beyzâ, Hz. Mûsâ, bâzûbend, şem", lù'bet, lûle, şiir, devât, name gibi öğelerin oluşturmasinda bu ince, uzun, beyaz, güzel ve zarif özelliklerinin etkili olduğu açıktır". ${ }^{91}$

Es'ad Efendi'nin aşağıdaki beytinde zambak ve zarafet ilişkisinden dolayı zambak, zekanın müşebbehi olarak kullanılmıştır:

Zanbak zekan cebîn-i münevver gül-i beyaz

Hûy jâle dîde nergis-i mestâne-bîn ola (Es'ad Efendi K 7/10) ${ }^{92}$

88 Cemal Kurnaz, Hayâlî Bey Divânı'nın Tahlîli, İstanbul, M.E.B., 1996, s. 369.

89 Tolasa, Ahmet Paşa, s. 480.

90 Onay, Açıklamalı Divan Şiiri Sözlüğü, s. 416.

91 Bayram, "Duygularin Dili ...", s. 216.

92 Doğan, a.g.e., s. 61. 


\section{Buhûrı Meryem}

İsminden dolayı Hz. İsâ'yı çağrıştıran buhûrı meryem "sevgilinin zülfü, hâme, Hz. İsâ, Mesîh, ve yed-i beyzâ imgeleri" yle birlikte kullanılır. ${ }^{93}$ Söz konusu çiçek çok az kullanılan bir çiçek olduğundan dîvânlarda buhurı meryemli kullanım bulmak bile zordur. Bayram'ın aktardığı Bâkî'ye ait beyit bunlardan biridir.

Dem-i Îsâ dirilir bûy-1 buhûr-1 Meryem

Açtı zanbak yed-i beyzâyı kef-i Mûsâ vâr ${ }^{94}$

Burada ilgi çekici olan iki farklı çiçeğin, iki peygamberle ilişki içinde olacak biçimde aynı beyitte kullanılmış olmasıdır. Buhurı meryem estetik açıdan daha çok Hz. İsa'ya telmih yapılan beyitlerde kullanılmıştır, denebilir.

\section{Leylak}

Oldukça seyrek kullanılan bir diğer çiçek olan leylak ise "mor veya beyaz renkli, kuvvetli kokulu olması sebebiyle; sonuna nisbet isi getirilerek, sevgilinin ayva tüyleri, zülfü ve elbisesini nitelemek üzere sifat konumunda değerlendirilmiştir." ${ }^{95}$ Leylakın taranmış olan yirmi altı dîvândan sadece üçünde ve üç beyitte yer aldığını belirten Bayram'ın verdiği örnek beyitlerden biri olan Nedîm'in beytinde leylak ve sevgilinin ayva tüyü arasında bir teşbih ilişkisi kurulmuştur:

Bir bâğdır cemâli ki gül-berg-i rûy-1 âl

Şebbûyu hâl sünbül ü leylâkı zülf ü hat ${ }^{96}$

Beyitte sevgilinin yüzü güle, beni şebboya, zülfü sünbüle ve ayva tüyü leylaka benzetilmiştir. Sevgilinin uzuvları ve çiçekler arasındaki temel benzerlik ilişkisi renk olmakla beraber şekil ve koku da önemli bir rol oynamaktadır. Leylak ve ayva tüyü ilişkisi de bu bağlamda değerlendirilebilir.

93 Bayram, "Duygularin Dili ...", s. 216.

94 Bayram, a.g.e., s. 632.

95 Bayram, "Duygularin Dili ...", s. 216.

96 Bayram, "Çiçeklerle Diğer Bitkilerin ...", s. 633. 


\section{Sonuç}

Klasik Türk şiirinde kullanılan çiçek çeşidi kısıtlıdır. 14 ve 15. yüzyıllardan sonra daha çok şiirde kendilerine yer buldukları anlaşılan çiçeklerin kullanım sıklığı sosyal yaşantıdan bağımsız değildir. Söz konusu dönemlerde müesses hâle gelen devlet yapılanması sonucu kentte ve bahçelerde daha çok görülmeye başlanan çiçekler, doğal olarak süsleme sanatlarında ve şiirlerde de daha sık kullanılır olmuşlardır. Bayram'ın da belirttiği üzere; “Divan şairleri, çiçekleri tüm yüzyıllarda gerçek anlamları ve bitkisel özellikleriyle uyumlu ve bağlantılı biçimde kullanmışlardır. Bunun yanında 15. yüzyılda çiçeklere gerçekçi ve doğal bakış açısının diğer yüzyıllara oranla daha kuvvetli olduğu, zamanla bu bakış açısının zayıfladığ söylenebilir." 97

Klasik Türk edebiyatında çiçekler, estetik birer obje olarak eserlerde kullanıldığ 1 gibi özellikle son dönemlerde bahçecilik ve çiçeklerle ilgili azımsanmayacak sayıda kitap kaleme alınmıştır. Nurhan Atasoy, konuyla ilgili çalışmasında dokuz tane Şükûfe-nâme, on yedi tane lâle risalesi, bir tane karanfil risalesi, on tane bostan risalesi ve on tane bahçecilikle ilgili kitap tespit etmiştir. ${ }^{98}$ Yukarıda sözü geçen Sümbül-nâme'yi de bu listeye eklemek mümkündür.

Daha önce dile getirdiğimiz gibi klasik Türk şairleri gerçekçi gözleme büyük önem vermişlerdir. Çiçeklerin "bitkisel özellikleriyle uyumlu ve bağlantıll" bir şekilde şiire konu olmalarının nedeni budur. Daha sonraki yüzyıllarda söz konusu yönelimin azalmasının sebebinin klasik Türk şiiri estetiğinin de klasik Türk şiiri gibi klasikleşmiş yani temel özelliklerinin belirlenmiş olmasıdır. Yerleşmiş bir estetik anlayış içinde dış dünyanın (burada çiçeklerin) tekrar tekrar gözlemlenmesine ihtiyaç duyulmamış olmalıdır. Nakış sanatında olduğu gibi şiirde de her şairin zihninde estetik gelenek tarafında belirlenmiş bir gül veya lâle imajı vardır. Şairler zihinlerinde hazır hâlde bulunan bu imajdan faydalanarak çiçekten estetik bir nesne olarak yararlanma yoluna gitmiş olmalıdırlar. Bu estetiğin en önemli özellikleri ise daha önce de belirtildiği üzere üsluplaştırma, i'caz, soyutlama gibi kavramlarda aranmalıdır. Söz konusu kavramlar, herhangi bir nesnede olduğu gibi çiçeklerde de muşahhas özellikler yerine ortak, genel özellikleri öne çıkarma eğilimindedir.

Her bir çiçek klasik Türk şiiri estetiği içinde kendine yer bulduğu oranda kullanılabilmiştir. Bunun için de kimi yapısal özelliklerinden soyutlanmıştır. Benzer bir durumun çiçek demetinden kullanım için seçilecek çiçekler için de estetik düzeyde yapıldığı söylenebilir. Çiçek demetinin kimi yönleri soyutlanmış, estetiğe uygun yönleri bırakılmış ve böylece şiire konu olmuştur. Böyle bir

97 Bayram, "Duygularin Dili ...", s. 218.

98 Nurhan Atasoy, Hasbahçe: Osmanlı Kültüründe Bahçe ve Çiçek, İstanbul, Aygaz A.Ş., 2002, s. 343-352. 
ameliye neticesinde klasik Türk şiirinde kullanılan çiçek sayısı nispeten azalmak durumunda kalmıştır. Daha önce de belirtildiği gibi Osmanlılar tarafından bilindiğiklerini belgeleyebildiğimiz haşhaş, gül hatmi, çuha çiçeği, çiğdem, ağlayan gelin, kadife çiçeği, açelya, katmerli düğün çiçeği, Peygamber çiçeği, Haseki küpesi, Kasımpatı, kardelen, sümbülbeter, çanta çiçeği, yalınkat gibi kimi çiçekler klasik estetiğe uygun hâle getirilemedikleri için şiirde pek kullanılmamışlardır. Sonuç olarak klasik Türk şiirinde çiçeklerin seçim ve kullanımı soyutlama/ üsluplaştırmaya dayalı, müesses, "sınırları belli" olan gelenekli estetik tarafından belirlemiştir. 


\section{Kaynakça}

Açıl, Berat, "Tûtî-i Mu'cize-gûyem: Osmanlı Şiirinin Estetiği", Modern Dönemde İslam'l ve Osmanlı'yı Yeniden Düşünmek, ed. Berat Açıl, M. Hüseyin Mercan, İstanbul, Yedirenk Yayınları, 2013.

Akdoğan, Yaşar, Ahmedî Dîvânından Seçmeler, Ankara, Kültür ve Turizm Bakanlığı Yayınları, 1988.

Andrews, Walter G., Şiirin Sesi Toplumun Şarkısı, çev. Tansel Güney, İstanbul, İletişim Yayınları, 2003.

Atasoy, Nurhan, Hasbahçe: Osmanlı Kültüründe Bahçe ve Çiçek, İstanbul, Aygaz A.Ş., 2002.

Aydemir, Yaşar, "Sünbüliyye", Türk Dünyası Ortak Edebiyatı Türk Dünyası Edebiyat Kavramları ve Terimleri Ansiklopedik Sözlü̈̆̈̈, cilt 5, Ankara, Atatürk Kültür Merkezi Başkanlığg Yayınları, 2006.

Ayvazoğlu, Beşir, Güller Kitabı, İstanbul, Ötüken Yayınları, 1997. , Ateş Çiçeği Lale, İstanbul, İstanbul Büyükşehir Belediyesi Kültür İşleri Daire Başkanlığı, 2003.

Ayverdi, Ekrem Hakk1, 18. Asırda Lâle, haz. M. Uğur Derman, İstanbul, Kubbealtı Neşriyat, 2006.

Bayram, Yavuz, "Çiçeklerle Diğer Bitkilerin Dîvân Şiirine Yansımaları ve Anlam Çerçeveleri”, (Yayımlanmamış Doktora Tezi), Ondokuz Mayıs Üniversitesi Sosyal Bilimler Enstitüsü, Samsun, 2001.

, "Burdur'un ve Divanların Gülü”, I. Burdur Sempozyumu, 16-19 Kasım 2005, Burdur, Mehmet Akif Ersoy Üniversitesi Rektörlüğü Yayınlar1, 2007.

, "Klasik Türk Şiirinde Duyguların Dili: Çiçekler", Turkish Studies International Periodical For the Languages, Literature and History of Turkish or Turkic, sayı 2/4, 2007.

Bozkurt, Nejat, Sanat ve Estetik Kuramlarl, İstanbul, Sarmal Yayınları, 1995.

Cevat Rüştü, Türk Çiçek ve Ziraat Kültürü Üzerine Cevat Rüştü'den Bir Güldeste, haz. Nazım Hikmet Polat, İstanbul, Kitabevi Yayınları, 2001.

Ceylan, Gürkan, Osmanlı'dan Günümüze Dört Gözde Çiçek: Güller, Karanfiller, Lâleler ve Sümbüller, İstanbul, Flora Yayınc1lık, 1999.

Dedes, Yorgos-Sperl, Stefan, “Her varak bir nüktedür gülşende': Üç Osmanlı kasîdesine Arap ḳașîdesi açısından bir bakış", Eski Türk Edebiyatı Çalışmaları VIII: Kasîdeye Medhiye: Biçime, İsleve ve Muhtevaya Dair Tespitler, haz. Hatice Aynur vd., İstanbul, Klasik Yayınları, 2013. 
Demirel, Şener, “Türk Şiirinde Erguvan' Üzerine Bir Deneme”, Uluslararası Türklük Bilgisi Sempozyumu, Erzurum, 25-27 Nisan 2007.

Demiriz, Yıldız, Osmanlı Kitap Sanatında Natüralist Üslupta Çiçekler, İstanbul, İstanbul Üniversitesi Edebiyat Fakültesi Yayınları, 1986.

Demiriz, Yıldız, Osmanlı Kitap Sanatlarında Doğal Çiçekler, İstanbul, Yorum Sanat, 2005.

Doğan, Muhammet Nur, Şeyhülislam Es'ad ve Dîvânı, İstanbul, M.E.B., 1997.

Emrî, Emrî Dîvânı, haz. M. A. Yekta Saraç, İstanbul, Eren Yayıncılık, 2002.

Erdem Günyüz, Melike, “Ahmedî Divanı'nın Tahlili”, (Yayımlanmamış Doktora Tezi), İstanbul Üniversitesi Türkiyat Enstitüsü, İstanbul, 2001.

Evyapan, Gönül Aslanoğlu, Eski Türk Bahçeleri ve Özellikle Eski İstanbul Bahçeleri, Ankara, Ortadoğu Teknik Üniversitesi, 1972.

Karaman, Gülay, "Perîşân Çiçek Sünbül ve Klasik Türk Şiirinde İşleniği", İnsan ve Toplum Bilimleri Araştırmaları Dergisi, sayı 1/2, 2012.

Koç, Turan, İslam Estetiği, İstanbul, İSAM Yayınları, 2009.

Kurnaz, Cemal, "Gül”, TDV İslam Ansiklopedisi, cilt 14, 1996. , Hayâlî Bey Divânı'nın Tahlîli, İstanbul, M.E.B., 1996.

Mengi, Mine, "Divan Şiiri Estetiği Açısından İ'câz", A. Ü. Türkiyat Araştırmaları Dergisi, say1 39, 2009.

Onay, Ahmet Talat, Açıklamalı Divan Şiiri Sözlü̆̆̈̈, haz. Cemal Kurnaz, Ankara, Birleşik, 2007.

Önal, Sevda, "Klasik Türk Edebiyatında Lâle ve Edebi Bir Tür Örneği Olarak Lâle Şiirleri”, Turkish Studies: International Periodical for the Languages, Literature and History of Turkish or Turkic, say1 4/2, 2009.

Öner, Esra, “Nâbî Dîvânı'nda Teşbih Unsuru Olarak Çiçekler”, (Yayımlanmamış Yüksek Lisans Tezi), Fatih Üniversitesi Sosyal Bilimler Enstitüsü, İstanbul, 2004.

Öztekin, Nezahat, "Eski Türk Edebiyatında Gül”, Kubbealtı Akademi Mecmuasl, say1 34/4, 2005.

Platon, Devlet, çev. Sabahattin Eyüboğlu, M. Ali Cimcoz, İstanbul, İş Bankas1 Yayınlar1, 2009.

Poyraz, Yakup, "Blossoming of the Love: Flowers and Love in the Ottoman Poetry", IIB International Refereed Academic Social Sciences Journal, say1 15, 2014. 
Schick, İrvin Cemil, "Aesthetics and Islamic Calligraphy", Eternal Letters, adlı sergide sunulmuş tebliğ, Sharjah.

, Bedeni, Toplumu, Kâinatı Yazmak: İslâm, Cinsiyet ve Kültür Üzerine, haz. Pelin Tünaydın, İstanbul, İletişim Yayınları, 2011.

Sefercioğlu, M. Nejat, Nev'î Divanı'nın Tahlîli, Ankara, Akçağ Yayınları, 2001 .

Sinan Nizam, Betül, "Divan Şiirinin Alegorik Âşık ve Maşuklarından Gül ü Bülbül”, Turkish Studies, say1 5/3, 2010.

Stendhal, Henri Beyle, Kırmızı ve Siyah, çev. Cevdet Perin, İstanbul, Remzi Yayınevi, 2002.

Tansuğ, Sabiha, Türklerde Çiçek Sevgisi ve "Sümbülname”, İstanbul, Ak Yayınlar1, 1998.

Tarlan, Ali Nihat, Necati Beg Divanı, İstanbul, M.E.B., 1997.

Tolasa, Harun, Ahmet Paşa 'nın Şiir Dünyası, 2. bs., Ankara, Akçağ, 2001.

Turgut, Hilal, "Tarihi Türk Bahçelerinde Havuz Yapıları", Tarih Kültür ve Sanat Araştırmaları Dergisi, sayı 1/3, 2012.

Yazar, İlyas, "Necâtî Bey'in Gazellerinde Açan Çiçeklerin Sultan1 'Gül”, Turkish Studies, say1 4/8, 2009.

Yeniterzi, Emine, Divan Şiirinde Na 't, Ankara, Türkiye Diyanet Vakfı Yayınlar1, 1993.

Yetkin, Suut Kemal, Estetik Doktrinler, İstanbul, Palme Yayınc1lık, 2007.

Yılmaz, Ozan, "Klasik Türk Edebiyatı'nda Bir Başka Anlamıyla 'Bahar”, Ankara Üniversitesi Dil ve Tarih-Coğrafya Fakültesi Türkoloji Dergisi, sayı 18, 2011. 